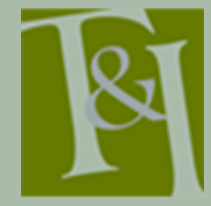

The International Journal for Translation \& Interpreting Research trans-int.org

\section{Translation vis-à-vis democratic deficit in the digital era: Policies, practices and possibilities of institutional translation in increasingly diverse societies}

\author{
M. Rosario Martín Ruano \\ University of Salamanca, Spain \\ mrmr@usal.es
}

DOI: 10.12807/ti.11222.2020.a05

\begin{abstract}
This article addresses the seemingly indisputable association between multilingualism, translation and democracy that is often expressed or implied in official institutional discourses at national and international levels. To this end, based on recent approaches from disciplines including political theory, sociology and translation studies, the author critically examines the interrelationship between translation policies and practices and democracy, which is itself considered to be a concept "in translation". Additionally, by drawing on a number of examples from different institutional settings, this article sheds light on some of the challenges facing institutional translation in today's digital age. Here, institutional translation emerges as an unavoidably political and interventionist task that is conditioned by - and an active part of - the asymmetrical dynamics which exist between identities in the increasingly technologised and diverse societies of our global era.
\end{abstract}

Keywords: institutional translation; democracy; multilingualism; asymmetry; power.

\section{Introduction}

Both at national and international level, institutions often actively express their support for multilingualism as a fundamental cornerstone of cohesive and inclusive multicultural societies. Multilingual communication within institutional settings is often something which is explicitly depicted as an active form of acknowledging and promoting the linguistic and cultural diversity of a given territory. Moreover, multilingualism is an element which is frequently cited in relation to the highest principles and ideals of democratic societies, including equality and pluralism. Within this mindset, translation is regularly brought into play as an activity of prime importance for recognising, promoting and strengthening multilingualism, and, therefore, as a key tool for realising the egalitarian ideals which multilingualism aims to attain (Sosoni, 2005). In this regard, translation has been praised for ensuring the sameness of languages and citizens before institutions and the law (Wagner et al., 2002); for guaranteeing the "citizens' fundamental democratic right to communicate with the authorities" (Meylaerts, 2011, p. 165), and for recognising, respecting and enhancing linguistic and cultural differences. These differences are currently shaped as a value to be cherished and promoted on an institutional level. At first glance, the association of multilingualism, translation, equality, and plurality

Translation \& Interpreting Vol. 12 No. 2 (2020) 
may seem indisputable. However, the role and significance of translation in furthering both linguistic and cultural diversity, and equality, are in fact diverse, as they are dependent on the complex interplay between many variables and factors, as the examples included in these pages will show.

A cursory analysis of the official web portal of the European Union provides a useful aid for distinguishing the institutional narratives which have been constructed around multilingualism. The information published on official EU websites in recent years enables us to perceive the force of this correlation between concepts and values, as well as to discern how these have changed over time. Not so long ago, the home page of the Directorate-General for Translation (as consulted in June 2016) informed the reader that "the EU policy of communicating in 24 official languages (multilingualism policy) is unique in the world. All official languages enjoy equal status. EU citizens in the 28 member countries can use any of them to communicate with the European institutions, which helps to make the Union more open and more effective" (DGT, 2016a). Subsequently, translation was expressly presented as a key success factor within a policy which was designed to promote inclusivity: "[a] multilingual organization like the EU needs high quality translation and relies on professional linguists to keep it running smoothly. The role of the language services in the various EU institutions and bodies is to support and strengthen multilingual communication in Europe and to help Europeans understand EU policies" (DGT, 2016a). As of late, this recurrent encomiastic view on translation, framed in a similarly panegyric higher-order discourse on multilingualism (Ammon \& Kruse, 2013), seems to have given way to more nuanced statements about the actual and potential contribution of translation to multilingualism, to language diversity and language equality, and, ultimately, to the equality of citizens across a multilingual Europe.

In this regard, despite the fact that translation has figured prominently as a key cornerstone of the EU's multilingual policy for several decades, the turn of the century (more precisely, the Barcelona European Council of March 2002) and the past five years in particular have seen a growing emphasis on language learning as a pillar of multilingualism. This process has resulted in specific actions and measures (Council of the European Union, 2014; European Commission, 2018). This shift is also reflected in one of the main webpages devoted to explaining the meaning and facets of the EU's multilingualism policy (European Union, 2019a), which states the goals of multilingualism ("striving to protect Europe's rich linguistic diversity" and "promoting language learning"). In contrast to information published in previous years, references to translation are noticeably scarce here, and seemingly quite incidental. The contents of the page concerning "language policy" (European Union, 2019b), as consulted in February 2019, provide insights as to how the abstract and optimistic narrative of the equal status of languages has been replaced by more detailed descriptions and explanations of the current linguistic regime, which actually involves the selection of certain languages over other ones that are excluded in certain contexts. In other words, there is evidence of a strategic prioritisation that is justified with arguments which revolve around the ideas of rationalisation and streamlining. The section "Why isn't a particular webpage available in your language?" (European Union, 2019b) is extremely revealing, as it features translation as a "constraint" - and what is more, a time-consuming and costly one-which ultimately explains and legitimises current and future limitations when it comes to the availability of content in and for certain languages. 
This example very clearly illustrates that widespread associations such as the quasi-natural link between translation and priorities currently on the agenda of institutions at national and international level (including the promotion of multilingualism, the expression of diversity and/or the extension of the principle of equal treatment) need to be approached critically. The analysis of their complex interrelationship needs to take into account wider linguistic and cultural dynamics which operate on a global scale, as well as a multiplicity of factors that are always at play in the broader context in which a particular translation takes place. However, as authors including Sandrini (2016, p. 52) have pointed out, translation has been consistently neglected in studies on language policies. As a reaction, interest in the fundamental, yet frequently unnoticed role that translation plays in the organisation, management and redefinition of the increasingly multilingual and ethno-culturally diverse societies of our global era has grown in recent years within the field of translation studies. More specifically, interest has increased within those studies which are devoted to "translation policies" - an expanding area of research (Meylaerts, 2011; González Núñez, 2016; González Núñez \& Meylaerts, 2017a) which, nevertheless, is considered to be "still in its infancy" by two of its main proponents (Meylaerts \& D'hulst, 2019). Although still scarce, existing studies on this promising field focus on implicit and explicit organisational practices which have a bearing on the performance and behaviour of translation when it comes to managing communication within multilingual societies, as well as on the ideologies and factors that shape and condition language and translation service provision in institutional settings.

For the purposes of this article, the concept of "translation policies" proves to be particularly revealing. González Núñez and Meylaerts (2017b, p. 2) highlight that the term typically encompasses "a series of intentionally coherent decisions on translation or translation activities made by public, and sometimes private, actors in order to resolve collective linguistic and translation problems" as well as "decisions that are not meant to be coherent [...] uncoordinated decisions that interact to create a policy in terms of translation". These authors stress the importance of "translation management, translation practice and translation beliefs" in the shaping of such policies (González Núñez and Meylaerts, 2017, p. 2). This article agrees with studies on translation policies which express the need to gain deeper insights into the workings of translation in institutional settings, where translation is often the result of - and complies with - specific policies which are designed for particular purposes, yet where, at the same time, translations are also often produced in the absence of a predefined strategic aim, of broader objectives and even of specific instructions. In this regard, it should not be forgotten that, despite the diversity and heterogeneity of practices which fall under the umbrella of "institutional translation" (Kang, 2009), expectations linked to what Venuti (1998a, p. 82) has termed an "ethics of sameness" continue to have a powerful grip in institutional settings: specialised literature has identified the model of "translation by default" as pervasively dominant in this overarching realm (Mayoral 2003, p. 42). In order to analyse the effects of another recurrent idea in the discourse on institutional translation, this article explores the influence of and inherent contradictions in the frequent association of translation and democracy in current institutional scenarios. Drawing on a discussion of theory and a number of examples from various institutional settings, the author will use the next few pages to explore the extent to which translation unfolds as a tool for democracy, as well as to discern whether certain deeply-entrenched expectations about translation may limit and hamper their ability to reinforce one another. This will 
include a discussion of the effects of the pre-eminence of a translation model based on an "ethics of sameness" in the institutional realm.

\section{Translation and democracy: which type of translation for which type of democracy?}

At various levels, the contemporary discourse of institutions often incorporates constructs of translation in which it is portrayed as an instrument that serves to promote and reinforce the ideals and values of democracy. This is explicitly the case in the following excerpt (DGT, 2016b):

As a democratic organisation, the EU has to communicate with its citizens in their own language. The same goes for national governments and civil services, businesses and other organisations all over the EU. Europeans have the right to know what is being done in their name in order to be able to play an active part.

As in the quoted example, translation is often conceived and projected as a guarantee of the right to information which underlies current conceptualisations of democracy, which demonstrate close links to the notions of universal representation and inclusivity - in other words, to political equality and participation. However, instead of being self-evident concepts, both translation and democracy are themselves contested constructs which lend themselves to being interpreted and updated according to different, sometimes contradictory, paradigms. For this reason, unravelling what is actually understood by "democracy" and "translation" in a given discourse or setting is vital for understanding their alleged or potential interaction. This (self-)reflexivity is also crucial for ultimately identifying the drawbacks and shortcomings which might restrict translation's ability to serve the interests of democracy.

Although democracy is often defined as rule or government by the people, the term rarely comes without adjectives or clarifications, because this does not remove the need to spell out what is understood by "the people" or the extent to which and by what means they are supposed to govern and rule. Even basic books on the subject acknowledge the existence of various types, forms and ideals of democracy. Munroe (2002, pp. 47-54), for instance, distinguishes between direct and/or participatory democracy vs. indirect or representative democracy, the democracy of so-called "welfare" vs. "minimalist" states according to the "nature and role of the market in relation to the public sector" (53), and presidential, semi-presidential and parliamentary democracies. Held (2006) examines four classic models of democracy, each with a number of variants: the classical model, influenced by the idea of democracy in ancient Athens; the republican model, either in the form of a protective or a developmental republicanism; the liberal model, which also has a protective and developmental variety, and the Marxist concept of direct democracy. In turn, these are complemented by an additional list of contemporary understandings of democracy, including competitive elitist democracy, pluralism, legal democracy, participatory democracy and deliberative democracy (Held 2006, p. 5). In a more general distinction, Lijphart (2012) contrasts a "majoritarian model of democracy", in which government action is expected to conform to the wishes of the bare majority in whose hands power is concentrated, with a "consensus model of democracy" which promotes broad participation and seeks to expand and enhance agreement on the decisions which are to be adopted through negotiation and compromise, etc. A review of current literature on political theory also reveals that the subtypes and variations of democracy are 
endless. Thus, although the concept of democracy is often invoked without nuances or reservations, and although it seems to have been internationally espoused or projected as a universally desirable objective in our day and age, it is far from being a crystal-clear concept or a well-defined target.

A number of authors have approached democracy in a manner which is very revealing for the purposes of this article: as a construct "in translation". Adopting a diachronic approach to the history of ideas, Lianeri's $(2000,2002)$ research presents democracy as an ambiguous and ambivalent concept that, like translation, has changed over time. In other words, it is posited as a concept which has been and will need to be continuously translated and redefined - both as a result of, and confirming, its own historicity. Schaffer's (1998) study on the understanding and procedures of democracy in non-Western political systems sheds light on the processual nature and context-bound meanings of democracy, calling into question not only the universality but also the universal appeal of dominant concepts and practices linked to democratic values. With a language-based analysis, Schaffer brings to light cross-cultural differences in the perception and appraisal of features and methods considered to be at the very core of democratic systems (such as elections or certain institutional arrangements) and argues that, far from universal, such features and methods are translated and interpreted differently in different locations. Nevertheless, other authors have warned against the direct "translatability" of purportedly democratic values and practices, and have expressed concerns both about the results of and methods for the promotion of democracy, for instance in the light of recent actions and interventions carried out in the name of spreading democracy as spearheaded by North American and European countries in third countries (Magen et al., 2009).

While disparities in the understanding of democracy across the globe show the undecidability of a concept that is, at its core, ambivalent and instable, democracy can also be considered to be "in translation" within those spaces which allegedly share a common worldview or mindset. In this regard, while the promotion of equality, participation and freedom of choice have been identified as core principles in cultures in which democracy is indisputably considered the bedrock of their political system, achieving and operationalising these ideals is something which requires complex acts of translation in order to realise and balance them adequately in different contexts. Far from being harmonious and complementary, these are intrinsically conflictual principles which compete with one another. For example, the search for equality may be understood to need a redressing of existing inequalities through differential treatment, yet it may be thought to be threatened by affirmative action. Participation is considered as something which is always encouraged, but sometimes it is merely used to delegate power to representatives, i.e. to enable citizens to shy away from decision-making. Ensuring individual autonomy may at times be considered to be at odds with the protection of common collective or specific group interests. In light of these tensions, democracy can also be understood as being "in translation". Indeed, democracy requires translating a set of ideals into practice. What is more, as has been highlighted by authors who have perceived a "structural affiliation between translation and the form of democracy" (McQuillan, 2009, p. 77) when adopting deconstructivist perspectives, democracy is something to be perpetually (de)constructed and reconstructed. In these approaches, democracy is but a promise full of aporias and contradictions. Translation emerges as a condition of democracy-a project that is always in the making. 
In addition to this, democracy has also been regarded as being "in translation" for it is - and will always be-far from perfect. A wealth of literature has examined the so-called "democratic deficit" of democratic societies. This term is used to describe situations in which democracies fail to perform adequately and fail to meet expected standards. Additionally, it refers to perceived structural deficiencies by which the workings of democracy seem to undermine the quality of democracy - to the point of yielding what are considered undemocratic results and/or of fostering practices that are at odds with democratic values. A number of scholars, most notably academics focusing on the context of the EU, have highlighted that causes of the identified "democratic deficit" include a lack of control and transparency, an excess of delegation, weakness, and the limited accountability of institutions (Majone, 1998; Katz, 2001; Crombez, 2003; Moravcsik, 2008; Norris, 2011). For the purposes of this article, it is especially relevant that democratic deficit has been linked to a communication deficit (Anderson, 2004; Michailidou, 2008), and this, in turn, to an "emotional deficit" in political and institutional communication (Richards, 2004). Curiously enough, a number of works have posited translation as remedial action-as a solution-for perfecting democracy in increasingly diverse societies. As recently underscored by Bielsa (2018), various sociologists, including Beck and Delanty, have praised the ability of translation, understood in a broad sense, to promote inclusion beyond sameness within the cosmopolitan project. Political philosophers such as Balibar and Archibugi have perceived the potential of translation as a dialogic activity for redefining public space within an increasingly transnational order, where the "universal" must find a common idiom in order to be able to be expressed beyond differences. On the other hand, departing from a more conventional definition of translation as a form of cross-linguistic and crosscultural negotiation, other authors have praised the possibilities for translation to express that what is not common, and as a tool for empowering the disenfranchised, to give a voice to marginal views which might otherwise remain unheard in purportedly democratic processes (Doerr, 2018a). The "democratizing potential" of translation has also been analysed in research which has been undertaken across a number of disciplines, including translation studies (Doerr, 2018b). Translation has been perceived as a democratic leveller in various senses: by contributing to bringing about change in non-democratic societies (Baker, 2016) and as part of transformative social movements (Boéri, 2012; Fernández, 2018), by enhancing dialogue and participation in increasingly diverse societies (Doerr, 2012), by enabling an engaged critique of existing hierarchies (Maier \& Boéri, 2010), by constituting a model for democracy beyond the nation-state (Doerr, 2018b) and/or an "instrument for multilingual democracy" (Pym, 2013).

Focusing specifically on the realm of institutional translation, this article maintains that translation (even in the form of non-translation) is unavoidably a feature in the functioning of institutions that currently operate in transnational and multilingual orders where particular versions of, or relations with, democracy need to be developed. However, it argues that it is not necessarily a promoter of democracy. The author contends that translation is at best an index of democracy, i.e. an indicator of the level and quality thereof, an opportunity for a particular form of democracy to be realised in a given context, as well as a test in which a society may assess the extent to which it can live up to the ideals of a certain concept of democracy. This argument is based on the conviction that " $[t]$ ranslation is never a benign process per se" (Cronin, 2003, p. 142). The effects and significance of translation need to be assessed both 
within and against the specificities of contexts where majorities and minorities maintain a particular balance of forces. It can be argued that any instance of institutional translation is always a political act, firstly because it operates within and has an impact on broader politics and policies (power relations among cultures, languages, ideologies, identities, communities of interest, etc.), and secondly because, either deliberately or inadvertently, it follows or embodies a particular policy or politics of translation. Depending on the context, a translation might make a message understandable, give voice to a collectivity or affirm the right to speak, but it might also imply or reveal misunderstandings and even the negation or exclusion of certain voices and identities when other ones are given the floor. Depending on the translation model chosen, linguistic and cultural differences will be managed differently and particular voices will be heard in a specific way: either as a distinctive, authoritative voice - clear and loud-, as a disembodied and distorted one that might sound awkward and strange, or as an alienated voice, depending on the perspective. Just like democracy, there is never a single definition and possibility of translation. Translation itself is also a concept which is "in translation", one which needs to be developed and even fine-tuned in context. It is my contention that particular translation practices may well show particular "translation deficits" when analysed from different angles. It is for this reason that, by drawing on several examples, I will now reflect on some of the challenges facing institutional translation today in the light of particular translation policies and practices currently existing in institutional settings.

\section{The building of democracies through institutional translation in today's asymmetrical orders}

In today's increasingly multilingual, multicultural and ethno-diverse societies, institutions cannot avoid taking a position when it comes to cultural and linguistic plurality. This is true both at national and international level, where a wide range of transnational interactions take place due to the fact that the ageold phenomena of cross-cultural contact and migration have assumed unprecedented dimensions in the globalised and networked society in which we live today. Institutional translation is one of the barometers that can be used to measure the capacity or determination of plural societies to deliberately recognise, display and enhance their diversity. In any event, although the existence of translation can, in certain cases, be read as a sign of democracy, equating the two could be misleading. Today, multilingual and translation policies are often defended and adopted in the name of democracy-something which has been demonstrated in the examples presented in the first section of this article and argued by authors such as Doerr (2009). Nevertheless, language diversity has traditionally been considered an obstacle to democracy, and one element undermining it (Kraus 2016, pp. 19-22). Indeed, classic concepts of democracy which are based on the logics of the nation-state idealise a unitary public sphere with one distinct common language that would allow communication on an equal footing and enhance integration through assimilation (Wright 2000, pp. 31-47). Kjaer and Adamo (2016, p. 2) have also recently expressed a warning in this line, alerting readers to the fact that "[1]inguistic diversity can be examined from many different perspectives that are usually mutually exclusive or competing". In the specific context of the EU, these authors underline that multilingualism can be perceived in different ways: as "a democratic value to be protected, a fundamental right of minority groups, 
an obstacle to deliberative democracy and a hindrance to legal certainty and the possibility of uniform law, a cultural asset of Europe to be promoted and protected, a competitive advantage of business on the market and a prerequisite for the free movement of EU citizens". As has, for example, been highlighted by Blommaert (2013), Karpinski (2014) and Moreno Cabrera (2016), many types of multilingualism exist, each of which varies greatly depending on the social prestige and institutional support of each of the languages involved. Therefore, the relations between multilingualism and translation also need to be thought of in the plural (Martín Ruano, 2018).

Even though comparing the use of translation across different communication policies of institutions in multilingual contexts can be extremely revealing of the willingness of said institutions to recognise social diversity and promote understanding, it can also hint at larger political issues and, at the same time, hide or obscure tensions and controversial debates. By way of an example, the contrast between the webpage of the Spanish Government (www.lamoncloa.gob.es), which offers citizens content in "Español", "Català", "Euskara", "Galego", "Valenciă" and "English", and the webpage of the Government of Gibraltar (www.gibraltar.gov.gi), which opts for monolingualism, brings to the fore the complexity of the variables which need to be taken into account when undertaking such a comparison. The comparison reveals a completely different strategy towards language diversity and a varying degree of willingness to be understood on the part of the competent authority in each case - which, in turn, might also be telling of the perceived need to make one's language understood, i.e. of existing hierarchies in the vertical stratification of languages in different contexts. It also underscores the significance of (non)translation, not only when it comes to reinforcing legitimacy, but also when it comes to gaining it. However, this example also makes clear that the "democratising effect" attributed to translation points in different, often contradictory, directions. The palette of languages reflected in the example does, to a certain extent, confirm the validity at institutional level of the "maxi-min language principle" theorised by van Parijs. According to van Doorslaer's (2019, p. 48), this principle explains the preference for languages that "minimise exclusion and thus linguistic discrimination in order to achieve maximally effective communication" when a heterogeneous multilingual audience is addressed. In the Spanish case, the example also shows the engagement of authorities and public institutions with initiatives to achieve a form of linguistic justice conceived as "parity of esteem" (van Parijs in van Doorslaer 2019, p. 49). In any case, translation's support of democracy cannot be linked merely to its instrumental capacity of enabling communication. Indeed, as has often been pointed out in the case of limited diffusion, minority or minorised languages, the reasons for using a particular language in institutional settings - i.e. to resort to (non)translation - often go beyond intercomprehension (Domènech, 2012). As the existence of a common language may serve the purposes of transmission but fall short of inclusivity, thus revealing structural exclusions, translation has been perceived as safeguarding ethnolinguistic democracy (Jiménez Salcedo \& Monzó, 2017) when entrenching minority rights, including language rights. Nevertheless, the inclusion of new languages may, in turn, imply a questioning of prior or alternative linguistic and translational regimes, whereby not only the relation between a minority and a hegemonic option may be contested, but also the relations between (minoritarian) options which may have different opinions on what constitutes a legitimate singularity. In this regard, far from promoting understanding, translation may also be used by institutions to increase the 
feeling of unintelligibility. Translation may be used to erect symbolic barriers between mutually understandable languages (Díaz Fouces, 2017, p. 70); it may serve to signal and establish differences amidst obvious similarities. As has been demonstrated time and time again throughout history, the official recognition of a new language is often preceded and followed by a large amount of institutional translation. The splitting of a formerly common language into separate official languages in the post-Yugoslav states is a paradigmatic case in point, where both formal policies and informal translational practices in contexts which can be termed as institutional cooperated in a project of linguistic differentiation (see, for example, Dragovic-Drouet, 2007, p. 30).

These examples show that institutional translation, and even institutional non-translation, can be conceptualised as a particularly insightful instance in which identities are being (re)constructed and negotiated within larger and conflictual processes which involve the recognition of rights, i.e. within democracy-building dynamics. From this point of view, institutional translation reveals itself to be more than just an instrument which might be, and indeed often is, politicised. Inevitably, institutional translation appears as a political act which, either deliberately or involuntarily, may grant or deny recognition to specific identities or sensibilities, add to or mitigate ongoing identitarian struggles. It may also take part in the exercise of symbolic violence of one particular identity over other identities. For this reason, it needs to be considered as an ideologically-loaded and highly politicised activity which may actively take part or result in the affirmation, alienation, negation or exclusion of identities fighting for representation in institutional settings. For the purposes of this article, it is particularly relevant to highlight that, in order to analyse and assess its political, ideological and identitarian implications, both its role in broader dynamics at macro-level in which it takes place and the effects of its decision-making at micro-level need to be examined. By locating a text within a linguistic repertoire and a network of forces, institutional translation takes on a unique position with regard to a given status quo. It also stages a particular mode of entextualisation where borders - and even barriers - between groups are managed through text-processing strategies and verbal choices. Furthermore, these two levels at which institutional translation operates need to be approached as complex interrelated spheres which weave connections in ways which are sometimes surprising and even paradoxical.

At macro-level, institutional translation is conditioned by and part of the redefinition of interactions between major and minor languages, cultures, identities and/or stakeholders which are characterised by marked asymmetries. As Venuti already remarked in a special issue which analysed the relation between translation and minority (1998, p. 135), "the terms 'majority' and 'minority' are relative". Furthermore, in today's global and interconnected village, these terms can no longer be conceived of as being involved in one-toone relations, but rather as being embedded in complex multilateral frameworks. The communication policy followed at the Frontier of the Peace Museum, located in the Portuguese town of Vilar Formoso, just metres away from one of the most important border crossings between Portugal and Spain, is a revealing example of the need to adopt a multi-sided approach. This memorial - devoted to Consul Aristides de Sousa Mendes and to the refugees who crossed into Portugal during World War II-is "conceived to provide the visitor/user with an audiovisual and interactive experience" (MVASM, 2020) through three corridors confronting them with the realities of "War", "Flight" and "Freedom". The brilliant panels and audiovisual material, presented in both Portuguese and English, make the museum a tourist attraction which appeals to 
an international public, yet it is not particularly inviting for Spanish-speaking visitors, the rather obvious niche of potential guests on the other side of the customs office. This example very graphically illustrates that the global order may be thought of as a "radial" system (Peña Martín, 2005), in which contact between peripheries, even in close vicinity - as is the case here-is often mediated by the centre. Institutional translation flows are uneven, with English indisputably occupying the central position of the current linguascape and an additional list of languages holding predominance over others by default whenever the act of translation is involved, despite the fact that these languages may be not relevant or may prove to be clearly superfluous or communicatively ineffective in particular contexts. This is something which has been noted with disappointment, for instance, in relation to the functioning of Public Service Translation and Interpreting services which engage with vulnerable groups such as migrants, refugees and asylum seekers. Within these settings, the limitations of languages which boast a "lingua franca" status and profess universality are laid bare. Beyond those "less translated languages" that Branchadell (2005, p. 1) places in opposition to those "source-language intensive languages", as identified by Cronin (2003), we can also find "excluded languages", which are frequently those of disadvantaged communities.

As a matter of fact, imbalances in translation flows not only occur among languages. When the representativeness of various language varieties and/or worldviews are compared, wide disparities can be seen even within a given language. Although English is the global language of international institutions (Crystal 2003, pp. 86ff), not all geographical locations across the globe contribute evenly to the production of international discourses mainstreamed in and by the English language. As shown, for example, by Maral-Hanak (2009) in a study that focused on the asymmetrical power relations within development policies, the language of international institutions carries the point of view of donors, but fails to include the terms and outlooks of target communities. When appraised critically, recurrent patterns in institutional translation show how it often takes part in, and perpetuates, uneven global processes of knowledgeproduction and opinion-shaping, deepening the North-South divide (Adams 1993). Translation is often a tool which propagates dominant discourses, subtly aggravating the marginalisation and exclusion of minority and peripheral actors. In addition to acting as a centripetal force, translation is also influenced by other centripetal forces, such as standardisation trends within languages, which are remarkably visible in institutional settings.

Indeed, at micro-level, institutional translation might result in disenfranchisement as a result of particular decisions to convey particular texts and messages, or of the absence of decisions. In extreme cases, institutions evidence a clear lack of capacity to acknowledge and effectively respond to the complexities of translation and even, it could be argued, to the requirements of democracy. Santander City Council's tourist information website, for instance, was made available in seven languages using Google Translate. When the translations received considerable media attention and were described as "sloppy", "ridiculous" and "embarrassing" (e.g. Heraldo, 2019), the authorities stood by their position that this machine translation system was widely used at institutional level and provided content in a financially competitive way. Certainly, translation may be an attempt to reach out to others, but expertise is required to adequately manage self-identity and to perceive the other's needs.

In any event, failure to reach the other may also occur when complying with professional models. This may be a side effect of institutional and professional ideologies that potentially need to be critically assessed, including 
the tendency towards standardisation. As has been pointed out time and time again in the case of Arabic, the default selection of the standard language variety for translation in contexts of diglossia or multiglossia may result in incomprehension. In heterogeneous cultural and linguistic geographies, translation needs to identify the variety most relevant for the target user or community (ElMadkouri \& Soto, 2002). In any case, other adaptations may be needed at the micro-level which take into account the specificities of the groups involved, for instance cultural assumptions, average literacy level, individual and group diversity, power imbalances (see, for instance, Taibi, 2007; Taibi \& ElMadkouri, 2016; Taibi \& Ozolins, 2016, pp. 29ff). In environments marked by cultural distance and asymmetries, contrary to guaranteeing equal treatment, the "ethics of sameness" which predominate in institutional settings have the potential to reinforce structural inequality as a result of difference-blind practices which unintentionally perpetuate unfamiliarity and stereotypes.

Nevertheless, these perils also lurk in institutional settings where diversity takes on more subtle forms and where it is to be managed within work processes and methods that already privilege a given approach to diversity. Research on translation quality in the context of the EU, for example, has identified the complex balances that need to be struck between accuracy, consistency and institutional continuity on the one hand, and users' expectations - especially in relation to clarity, readability, and fitness-for-purpose - on the other (Svoboda et al., 2017). At the same time, the quick and incessant advance of automated processes favours the highest degree of concordance, alignment and reusability, i.e. equivalence in terms of similarity, isomorphism, and literalness. Needless to say, these "ethics of sameness" do not necessarily lead to democratic equality. Achieving uniformity in a universe of differences and asymmetry implies unequal homogenisation, with cessions and concessions, accepted or indulged dominance, and levelling-out practices, potentially creating feelings of alienation and disaffection. In the global spaces of power created by intricate and asymmetrical networks shaped by institutional actors, as well as by technologies, translation encounters both new possibilities and new challenges when it comes to fulfilling its democratic vocation.

\section{Concluding remarks: possibilities and challenges for democratic translation in a digital, technological age}

Since the turn of the century, and in parallel with all sectors of the translation profession, institutional translation has experienced a Copernican revolution as a result of the rapid and unstoppable technologisation of work processes and of (at least Western) life in general that is bringing about the emergence of a posthuman rationality. In this scenario, translation is frequently seen as a new opportunity to remove barriers, to avoid discrimination, and to enable unrestricted access to a truly integrated common space created by technologies, including language technologies. The most recent official discourse by international institutions reflects the shift in narratives on translation "in the wake of the global expansion of the techno-scientific marketplace" identified by Baumgarten and Cornellà-Detrell (2019, p. 17), in which "the translation process itself is increasingly explained in the managerial terms of productivity and professional efficiency". Translation as a democratic practice takes on new meanings and new readings within a paradigm influenced by "the forces of techno-scientific rationality and capitalist globalisation" (Baumgarten \& Cornellà-Detrell, 2019, p. 17). 
Within academic circles (Pym, 2011), the industry and the general public, automated translation has been described as the great democratiser, allowing everyone to instantly understand and communicate across languages. And yet, without wishing to minimise the immense progress that machine translation and IT applications which support the translation process have brought about, it is also necessary to remain critical, so as "to scrutinise newly emerging yet constantly shifting hierarchies of power within the context of the digital economy of translation", as has been argued for by Baumgarten and CornellàDetrell $(2019$, p. 17). In a sense, this is also a call to constantly examine and assess the interrelationship of translation and various definitions of equality and democracy. Not all human beings have access to language technologies or even to language mediation; nor are all languages so well prepared as to guarantee the suitable performance of (technology-aided) translation in all language combinations. Additionally, as has been explained throughout these pages, every act of institutional translation entails exclusions and decisions at many levels which, as major scholars including Bassnett and Lefevere (1990, p. 11) and Hermans $(1996$, pp. 9, 16) warned, can never be considered to be innocent in nature. Translation implies choosing a major or a minor language or a major or minor variety thereof to the detriment of others; obeying or defying a particular linguistic norm; following certain conventions and a given tradition or failing to honour them, and privileging majoritising or minoritising strategies in texts which need to negotiate both the global and the local.

For these reasons, institutional translation emerges as an unavoidably interventionist task through which the political economy of languages is rearranged, a particular model for encompassing cultural difference is enacted, a certain regime of alterity is proposed and a symbolic order for coexistence or diversity is projected. Equality and equivalence are ever-present challenges, as are democracy and translation. Therefore, even though institutional translation may be initially promoted to serve democracy, the challenge of detecting potential "democratic deficits" within the model of democracy it serves will always lie ahead. Furthermore, it will always need to assess the "translation deficit" in the translation policies and/or practices adopted. Institutional translation will always have both the possibility of being and the challenge of becoming more "translational": more culturally sensitive, more attentive to specificities, and more favourable to the dialogical expression of diversity.

\section{Funding}

This work was supported by Ministerio de Economía y Competitividad and ERDF Funds. It is part of the research project VIOSIMTRAD, FFI2015-66516P MINECO/ERDF, conducted by the Research Group TRADIC (Translation, Ideology, Culture) at the University of Salamanca, Spain.

\section{References}

Adams, Nassau A. (1993). Worlds apart: The North-South divide and the international system. London: Zed Books.

Ammon, U., \& Kruse, J. (2013). Does translation support multilingualism in the EU? Promises and reality - the example of German. International Journal of Applied Linguistics, 23(1), 15-30. https://doi.org/10.1111/ijal.12017

Anderson, P. (2004). The great non-communicator? The mass communication deficit of the European Parliament and its Press Directorate. JCMS, 42(5), 897-917. https://doi.org/10.1111/j.0021-9886.2004.00534.x

Translation \& Interpreting Vol. 12 No. 2 (2020) 
Baker, M. (2016). The prefigurative politics of translation in place-based movements of protest: Subtitling in the Egyptian Revolution. The Translator, 22(1), 1-21. https://doi.org/10.1080/13556509.2016.1148438

Bassnett, S., \& Lefevere, A. (1990). Translation, history and culture. London: St. Martin's Press.

Baumgarten, S., \& Cornellà-Detrell, J. (2019). Translation and the economies of power. In S. Baumgarten \& J. Cornellà-Detrell (Eds.), Translation and global spaces of power (pp. 11-26). Bristol: Multilingual Matters.

Bielsa, E. (2018). Translation and cosmopolitanism. In F. Fernández \& J. Evans (Eds.), The Routledge handbook of translation and politics (pp. 110-124). London/New York: Routledge.

Blommaert, J. (2013). Ethnography, superdiversity and linguistic landscapes: Chronicles of complexity. Bristol: Multilingual Matters.

Boéri, J. (2012). Translation/Interpreting politics and praxis. The impact of political principles on Babels' interpreting practice. The Translator, 18(2), 269-290. https://doi.org/10.1080/13556509.2012.10799511

Branchadell, A. (2005). Less-translated languages as a field of enquiry. In A. Branchadell \& L. M. West (Eds.), Less translated languages (pp. 1-26). Amsterdam: John Benjamins.

Council of the European Union (2014). Conclusions on multilingualism and the development of language competences. Retrieved February 2019, from https://www.consilium.europa.eu/uedocs/cms_data/docs/pressdata/en/educ/1426 92.pdf

Crombez, C. (2003). The democratic deficit in the European Union. Much Ado about nothing? European Union Politics, 4(1), 101-120. https://doi.org/10.1177/ 1465116503004001583

Cronin, M. (2003). Translation and globalisation. London/New York: Routledge.

Crystal, D. (2003 [1997]). English as a global language. Cambridge: CUP.

DGT (Directorate-General for Translation of the European Commission) (2016a). Translation and the European Union. https://ec.europa.eu/dgt/translation/ translating/index_en.htm

DGT (Directorate-General for Translation of the European Commission) (2016b). Interpreting and translating for Europe. Brussels: European Commission [Brochure]. https://ec.europa.eu/info/sites/info/files/en_print_2016.pdf

Díaz-Fouces, Ó. (2017). From language planning to translation policy: Looking for a conceptual framework. In G. González Núñez \& R. Meylaerts (Eds.), Translation and public policy: Interdisciplinary perspectives and case studies. London/New York: Routledge.

Doerr, N. (2009). Language and democracy in movement. Social Movement Studies, 8(2), 149-165. https://doi.org/10.1080/14742830902770290

Doerr, N. (2012). Translating democracy: How activists in the European Social Forum practice multilingual deliberation. European Political Science Review, 4(3), 361-384. https://doi.org/10.1017/S1755773911000312

Doerr, N. (2018a). Political translation: How social movement democracies survive. Cambridge: CUP.

Doerr, N. (2018b). Translation and democracy. In F. Fernández \& J. Evans (Eds.), The Routledge handbook of translation and politics (pp. 64-78). London/New York: Routledge.

Domènech, O. (2012). Traduir del castellà al català, més enllà de la intercomprensió. Barcelona: Editorial UOC.

Dragovic-Drouet, M. (2007). The practice of translation and interpreting during the conflicts in the former Yugoslavia (1991-1999). In M. Salama-Carr (Ed.), Translating and interpreting conflict (pp. 29-40). Amsterdam: Rodopi.

El-Madkouri, M., \& Soto, B. (2002). La función de la interpretación en una sociedad de recepción (la complejidad lingüístico-cultural en el caso del inmigrante marroquí). In C. Valero \& G. Mancho (Eds.) Traducción e interpretación en los servicios públicos: nuevas necesidades para nuevas realidades (pp. 105-116). Alcalá: Universidad de Alcalá. http://www3.uah.es/traduccion/Actas/2002/libro. pdf

Translation \& Interpreting Vol. 12 No. 2 (2020) 
European Commission (2018). Proposal for a Council Recommendation on a comprehensive approach to the teaching and learning of languages. Retrieved February 2019, from https://eur-lex.europa.eu/legalcontent/EN/TXT/?uri=COM $\% 3 \mathrm{~A} 2018 \% 3 \mathrm{~A} 272 \% 3 \mathrm{AFIN}$.

European Union (2019a). Multilingualism. Retrieved February 2019, from https:// europa.eu/european-union/topics/multilingualism_en

European Union (2019b). Language policy. Retrieved February 2019, from https://europa.eu/european-union/abouteuropa/language-policy_en\#eu-officiallanguages

Fernández, F. (2018). Podemos: Politics as a "task of translation". Translation Studies, 11(1), 1-16. https://doi.org/10.1080/14781700.2017.1373695.

González Núñez, G. (2016). On translation policy. Target, 28(1), 87-109. https://doi.org/10.1075/target.28.1.04gon

González Núñez, G. \& Meylaerts, R. (Eds.) (2017a). Translation and public policy: Interdisciplinary perspectives and case studies. London /New York: Routledge.

González Núñez, G. \& Meylaerts, R. (2017b). Interdisciplinary perspectives on translation policy. New directions and challenges. In G. González Núñez \& R. Meylaerts (Eds.), Translation and public policy: Interdisciplinary perspectives and case studies (pp. 1-14). London/New York: Routledge.

Held, D. (2006 [1987]). Models of democracy. London/New York: Routledge.

Heraldo (2018). La "ridícula" traducción de la web de Turismo de Santander. Retrieved 15 July 2019, from https://www.heraldo.es/noticias/sociedad/2018/01/17/laridicula-traduccion-web-turismo-santander-1219601-310.html

Hermans, T. (1996). Translation's Other. Inaugural lecture. London: UCL.

Jiménez Salcedo, J. \& Monzó, E. (2017). Introducció. Les identitats minoritzades davant l'oportunitat del postmonolingüisme. In J. Jiménez Salcedo \& E. Monzó (Eds.), Les llengües minoritzades en l'ordre postmonolingüe (pp. 1-4). Castellón: Universitat Jaume I.

Kang, J.-H. (2009). Institutional translation. In M. Baker \& G. Saldanha (Eds.), Routledge encyclopedia of Translation Studies (pp. 141-145). London/New York: Routledge.

Karpinski, E. C. (2015). Invisible borders: Translation and multilingualism in an unequal world. Tusaaji: A Translation Review, 3(3), 21-34. https://doi.org/10. 25071/1925-5624.40281

Katz, R. (2001). Models of democracy. Elite attitudes and the democratic deficit in the European Union. European Union Politics, 2(1): 53-79. https://ecpr.eu/Filestore/ PaperProposal/3ed4ce15-e696-4f7e-b1bc-2a60f247d2b2.pdf

Kjaer, A.L., \& Adamo, S. (2011). Linguistic diversity and European democracy: Introduction and overview. In A. L. Kjaer \& S. Adamo (Eds.), Linguistic diversity and European democracy (pp. 1-16). London/New York: Routledge.

Kraus, P.A. (2011). Neither united nor diverse? The language issue and political legitimation in the European Union. In A. L. Kjaer \& S. Adamo (Eds.), Linguistic diversity and European democracy (pp. 17-35). London/New York: Routledge.

Lianeri, A. (2000). Translation and the shaping of modern democracy. In A. Chesterman, N. Gallardo \& Y. Gambier (Eds.), Translation in context (pp. 163176). Amsterdam: John Benjamins.

Lianeri, A. (2002). Translation and the establishment of liberal democracy in Nineteenth-Century England: Constructing the political as an interpretive act. In M. Tymoczko \& E. Gentzler (Eds.) Translation and power (pp. 1-24). Amherst: University of Massachusetts.

Lijphart, A. (2012 [1999]). Patterns of democracy: Government forms and performance in thirty-six countries. New Haven/London: Yale University Press.

Magen, A., Risse, T. \& McFaul, M.A. (Eds.) (2009). Promoting democracy and the rule of law: American and European strategies. Basingstoke/New York: Palgrave McMillan.

Maier, C. \& Boéri, J. (Eds.) (2010). Compromiso social y traducción/interpretación. Granada: ECOS.

Majone, G. (1998). Europe's "democratic deficit": The question of standards. European Law Journal, 4(1), 5-28. https://doi.org/10.1111/1468-0386.00040

Translation \& Interpreting Vol. 12 No. 2 (2020) 
Maral-Hanak, I. (2009) Language, discourse and participation - Studies in donordriven development in Tanzania. Vienna: Lit.

Martín Ruano, M.R. (2018). Unveiling and redressing inequality dynamics in legal and institutional translation: From symbolic violence to symbolic recognition. In E. Monzó \& J. Jiménez Salcedo (Eds.), Translating and interpreting justice in a postmonolingual age (pp. 35-59). Delaware: Vernon Press.

Mayoral, R. (2003). Translating official documents. Manchester: St Jerome.

McQuillan, M. (2009). Deconstruction after 9/11. London /New York: Routledge.

Meylaerts, R. (2011). Translation policy. In Y. Gambier \& L. van Doorslaer (Eds.), Handbook of translation studies 2 (pp. 163-168). Amsterdam: John Benjamins.

Meylaerts, R. \& D'hulst, L. (2019). Translation policy: Connecting concepts and writing history. CFP EST Conference. http://conferences.au.dk/est/panels/panel13-translation-policy-connecting-concepts-and-writing-history/

Michailidou, A. (2008). Democracy and new media in the European Union: Communication or participation deficit? Journal of Contemporary European Research, 4(4), 346-368. https://www.jcer.net/index.php/jcer/article/view/129

Moravcsik, A. (2008). The myth of Europe's "democratic deficit". Intereconomics, 43(6), 331-340. https://doi.org/10.1007/s10272-008-0266-7

Moreno Cabrera, J. C. (2016). Multilingüismo y lenguas en contacto. Madrid: Síntesis.

Munroe, T. (2002 [1993]). An introduction to politics. Kingston: Canoe Press.

MVASM, (2020). Aristides de Sousa Mendes Virtual Museum. Retrieved 15 July, from http://mvasm.sapo.pt/EV

Norris, P. (2011). Democratic deficit: Critical citizens revisited. Cambridge: CUP.

Peña Martín, S. (2005). En pocas palabras (VI). El Trujamán. http://cvc.cervantes.es/ trujaman/anteriores/junio_05/10062005.htm

Pym, A. (2013). Translation as an instrument for multilingual democracy. Multilingual, 1(2), 78-95. https://cms.arizona.edu/ojs3/multilingual/article/download/18/51/+\& $\mathrm{cd}=1 \& \mathrm{hl}=$ es \&ct $=\mathrm{clnk} \& \mathrm{gl}=\mathrm{es}$.

Richards, B. (2004). The emotional deficit in political communication. Political Communication, 21(3), 339-352. https://doi.org/10.1080/10584600490481451

Sandrini, P. (2016). Towards a digital translation policy. In D. Dejica, G. Hansen \& I. Para (Eds.), Language in the digital era. Challenges and perspectives (pp. 50-59). Berlin: de Gruyter Open.

Schaffer, F. C. (1998). Democracy in translation. Understanding politics in an unfamiliar culture. Ithaca/London: Cornell University Press.

Sosoni, V. (2005). Multilingualism in Europe. Blessing or curse? In A. Branchadell \& L.M. West (Eds.), Less translated languages (pp. 39-49). Amsterdam: John Benjamins.

Svoboda, T., Biel, Ł. \& Łoboda, K. (2017). Quality aspects in institutional translation: Introduction. In T. Svoboda, Ł. Biel \& K. Łoboda (Eds.), Quality aspects in institutional translation (pp. 1-13). Berlin: Language Science Press.

Taibi. M. (2007). El árabe en el ámbito de la traducción e interpretación en los servicios públicos. Puentes, 8, 5-10. wpd.ugr.es/ greti/revista-puentes/pub8/03-MustaphaTaibi.pdf

Taibi, M. \& El-Madkouri, M. (2016). Interpreting taboo: The case of Arabic interpreters in Spanish public services. In M. Taibi (Ed.) New insights into Arabic translation and interpreting (pp. 68-90). Bristol: Multilingual Matters.

Taibi, M. \& Ozolins, U. (2016). Community translation. London: Bloomsbury.

van Doorslaer, L. (2019). Turning minorities and majorities upside down. In S. Baumgarten \& J. Cornellà-Detrell (Eds.), Translation and global spaces of power (pp. 39-58). Bristol: Multilingual Matters.

Venuti, L. (1998a). The scandals of translation. Towards an ethics of difference. London/New York: Routledge.

Venuti, L. (1998b). Introduction. The Translator, 4(2), 135-144.

Wagner, E., Bech, S., \& Martínez, J.M. (2002). Translating for the European Union institutions. Manchester: St. Jerome.

Wright, S. (2000). Community and communication. The role of language in nation state building and European integration. Clevedon: Multilingual Matters. 